NASA/TM-2004-212959

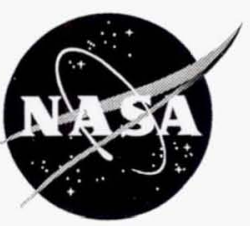

\title{
An Overview of Long Duration Sodium Heat Pipe Tests
}

John H. Rosenfeld, Donald M. Ernst, James E. Lindemuth, and James L. Sanzi Thermacore International, Inc., Lancaster, Pennsylvania

Steven M. Geng

Glenn Research Center, Cleveland, Ohio

Jon Zuo

Advanced Cooling Technologies, Inc., Lancaster, Pennsylvania 
Since its founding, NASA has been dedicated to the advancement of aeronautics and space science. The NASA Scientific and Technical Information (STI) Program Office plays a key part in helping NASA maintain this important role.

The NASA STI Program Office is operated by Langley Research Center, the Lead Center for NASA's scientific and technical information. The NASA STI Program Office provides access to the NASA STI Database, the largest collection of aeronautical and space science STI in the world. The Program Office is also NASA's institutional mechanism for disseminating the results of its research and development activities. These results are published by NASA in the NASA STI Report Series, which includes the following report types:

- TECHNICAL PUBLICATION. Reports of completed research or a major significant phase of research that present the results of NASA programs and include extensive data or theoretical analysis. Includes compilations of significant scientific and technical data and information deemed to be of continuing reference value. NASA's counterpart of peerreviewed formal professional papers but has less stringent limitations on manuscript length and extent of graphic presentations.

- TECHNICAL MEMORANDUM. Scientific and technical findings that are preliminary or of specialized interest, e.g., quick release reports, working papers, and bibliographies that contain minimal annotation. Does not contain extensive analysis.

- CONTRACTOR REPORT. Scientific and technical findings by NASA-sponsored contractors and grantees.
- CONFERENCE PUBLICATION. Collected papers from scientific and technical conferences, symposia, seminars, or other meetings sponsored or cosponsored by NASA.

- SPECIAL PUBLICATION. Scientific, technical, or historical information from NASA programs, projects, and missions, often concerned with subjects having substantial public interest.

- $\quad$ TECHNICAL TRANSLATION. Englishlanguage translations of foreign scientific and technical material pertinent to NASA's mission.

Specialized services that complement the STI Program Office's diverse offerings include creating custom thesauri, building customized databases, organizing and publishing research results ... even providing videos.

For more information about the NASA STI Program Office, see the following:

- Access the NASA STI Program Home Page at http://www.sti.nasa.gov

- E-mail your question via the Internet to help@sti.nasa.gov

- Fax your question to the NASA Access Help Desk at 301-621-0134

- Telephone the NASA Access Help Desk at 301-621-0390

- Write to: NASA Access Help Desk NASA Center for AeroSpace Information 7121 Standard Drive Hanover, MD 21076 
NASA/TM-2004-212959

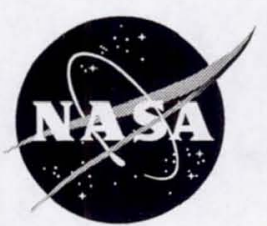

\section{An Overview of Long Duration Sodium Heat Pipe Tests}

John H. Rosenfeld, Donald M. Ernst, James E. Lindemuth, and James L. Sanzi Thermacore International, Inc., Lancaster, Pennsylvania

Steven M. Geng

Glenn Research Center, Cleveland, Ohio

Jon Zuo

Advanced Cooling Technologies, Inc., Lancaster, Pennsylvania

Prepared for the

Space Technology and Applications International Forum (STAIF-2004) sponsored by the American Institute of Physics

Albuquerque, New Mexico, February 8-12, 2004

National Aeronautics and

Space Administration

Glenn Research Center 


\section{Acknowledgments}

The work described in this paper was performed by Thermacore International, Inc. for several customers. The one tenth segment heat pipe life test was designed and built under NASA Contract No. NAS3-26925, and has been continued under a series of extensions through the NASA Glenn Research Center. The bench top, hybrid receiver, and pressure relief device life tests were designed and built with funding provided by Cummins Power Generation, Inc. Partial funding for the hybrid receiver life test was provided by the National Renewable Energy Laboratory under Contract No. ZA-2-11120-1. The authors also wish to acknowledge the many engineers and technicians who participated in the design, fabrication, and testing work described herein.

This report is a formal draft or working paper, intended to solicit comments and ideas from a technical peer group.

Trade names or manufacturers' names are used in this report for identification only. This usage does not constitute an official endorsement, either expressed or implied, by the National

Aeronautics and Space Administration.

Available from

NASA Center for Aerospace Information

National Technical Information Service

7121 Standard Drive 5285 Port Royal Road

Hanover, MD 21076 Springfield, VA 22100 


\title{
An Overview of Long Duration Sodium Heat Pipe Tests
}

\author{
John H. Rosenfeld, 'Donald M. Ernst, James E. Lindemuth, and James L. Sanzi \\ Thermacore International, Inc. \\ Lancaster, Pennsylvania 17601 \\ Steven M Geng \\ National Aeronautics and Space Administration \\ Glenn Research Center \\ Cleveland, Ohio 44135 \\ Jon Zuo \\ Advanced Cooling Technologies, Inc. \\ Lancaster, Pennsylvania 17601
}

\begin{abstract}
Summary
High temperature heat pipes are being evaluated for use in energy conversion applications such as fuel cells, gas turbine re-combustors, and Stirling cycle heat sources; with the resurgence of space nuclear power, additional applications include reactor heat removal elements and radiator elements. Long operating life and reliable performance are critical requirements for these applications. Accordingly, longterm materials compatibility is being evaluated through the use of high temperature life test heat pipes. Thermacore, Inc., has carried out several sodium heat pipe life tests to establish long term operating reliability. Four sodium heat pipes have recently demonstrated favorable materials compatibility and heat transport characteristics at high operating temperatures in air over long time periods. A 316L stainless steel heat pipe with a sintered porous nickel wick structure and an integral brazed cartridge heater has successfully operated at 650 to $700{ }^{\circ} \mathrm{C}$ for over 115,000 hours without signs of failure. A second $316 \mathrm{~L}$ stainless steel heat pipe with a specially-designed Inconel 601 rupture disk and a sintered nickel powder wick has demonstrated over 83,000 hours at 600 to $650^{\circ} \mathrm{C}$ with similar success. A representative onetenth segment Stirling Space Power Converter heat pipe with an Inconel 718 envelope and a stainless steel screen wick has operated for over 41,000 hours at nearly $700{ }^{\circ} \mathrm{C}$. A hybrid (i.e., gas-fired and solar) heat pipe with a Haynes 230 envelope and a sintered porous nickel wick structure was operated for about 20,000 hours at nearly $700{ }^{\circ} \mathrm{C}$ without signs of degradation. These life test results collectively have demonstrated the potential for high temperature heat pipes to serve as reliable energy conversion system components for power applications that require long operating lifetime with high reliability. Detailed design specifications, operating history, and test results are described for each of these sodium heat pipes. Lessons learned and future life test plans are also discussed.
\end{abstract}

\section{Introduction}

High temperature heat pipes are being evaluated for use in energy conversion applications such as fuel cells, gas turbine re-combustors, and Stirling cycle heat sources; with the resurgence of spacc nuclear power, additional applications include reactor heat removal elements and radiator elements. In the temperature range between 500 and $1000^{\circ} \mathrm{C}$, heat pipes can offer the favorable features of passive, reliable operation, effective thermal coupling between non-contacting fluid streams, and modest cost (Rosenfeld and Ernst, 1999). Long operating life and reliable performance are critical requirements for

PPhone: 717-569-6551,E-mail: j.h.rosenfeld@thermacore.com 
these applications. Reliability for space-based applications is particularly critical because component replacement is generally difficult or impossible.

Heat pipes are a key component under consideration for the higher-power dynamic power systems. NASA Glenn Research Center has been involved in the development of dynamic power converters for both nuclear and solar power conversion systems. Of particular current interest are: 1) the development of a Stirling Radioisotope Generator (SRG) as a possible high efficiency alternative to Radioisotope Thermoelectric Generators (RTGs) for deep space missions and unmanned Mars rovers, and 2) higherpower Brayton and possibly Stirling or Rankine power systems for nuclear electric propulsion and power applications. Thermal energy is generally supplied at a high temperature $(>1000 \mathrm{~K})$ to the power conversion system. High temperature heat pipes are one option to efficiently transfer thermal energy from the nuclear reactor heat source to the dynamic power converter. Heat pipes may also be useful for transferring waste heat from the power converter to the radiator. Heat pipes and other passive technologies are currently being considered for the purpose of transferring heat from the power converter to the radiator with minimal temperature drop and to spread heat within the radiator panels isothermally.

Stirling heat engines are being developed for electrical power generation on manned and unmanned earth orbital and planetary missions and also for terrestrial applications for utility and remote power generation. Dish Stirling solar systems and nuclear reactor Stirling systems are two promising applications of Stirling engine technology. Sources of thermal energy used to drive the Stirling engine typically have non-uniform temperatures and heat fluxes. Liquid metal heat pipe receivers are often used as heat transformers to uniformly deliver thermal energy at high temperatures to the heater heads of these Stirling engines. The use of heat pipe receivers can greatly enhance system efficiency and potential life span.

One issue that needed to be addressed during the design phase of heat pipe receivers is the potential solubility corrosion of the heater head section by the liquid metal working fluid. Stainless steels and nickel-based superalloys are standard materials of construction for high temperature heat pipes and heater heads operating in the temperature range 823 to $1073 \mathrm{~K}$. At these operating temperatures, some components of these materials are appreciably soluble in working fluids such as sodium, potassium, and $\mathrm{NaK}$. Over a typical life span of seven to ten years, essentially pure working fluid condensate will condense on the heater head surfaces. The condensate will leach the soluble components of the heater head material and transport them to the evaporator section of the heat pipe. When the working fluid is evaporated again, the soluble materials are precipitated and essentially pure working fluid is returned to the condenser section to leach more material. The condensation heat flux for a Stirling heater head is typically 20 to $25 \mathrm{~W} / \mathrm{cm}^{2}$. For a 33 percent efficient $25 \mathrm{~kW}_{\mathrm{e}}$ Stirling engine this corresponds to approximately 760,000 liters of sodium per year, condensing on a heater head.

To establish long term operating reliability for sodium heat pipes, several long-duration sodium heat pipe life tests were performed. This paper describes the design and performance results from these tests, which collectively establish the capability of sodium heat pipes in applications requiring high reliability over long time durations.

\section{Long Duration Life Tests: Description and Results}

Four long-duration sodium heat pipe life tests have demonstrated favorable results in recent tests. A 316L stainless steel heat pipe with a sintered porous nickel wick structure and an integral brazed cartridge heater has successfully operated at 650 to $700{ }^{\circ} \mathrm{C}$ for over 115,000 hours without signs of failure. A second $316 \mathrm{~L}$ stainless steel heat pipe with a specially-designed Inconel 601 rupture disk and a sintered nickel powder wick has demonstrated over 83,000 hours at 600 to $650{ }^{\circ} \mathrm{C}$ with similar success. A representative one-tenth segment Stirling Space Power Converter heat pipe with an Inconel 718 envelope and a stainless steel screen wick has operated for over 41,000 hours at nearly $700{ }^{\circ} \mathrm{C}$. A hybrid (i.e., gasfired and solar) heat pipe with a Haynes 230 envelope and a sintered porous nickel wick structure was 
operated for about 20,000 hours at nearly $700^{\circ} \mathrm{C}$ without signs of degradation. Detailed design specifications, operating history, and test results are described for each of these sodium heat pipes.

\section{One Tenth Segment Stirling Space Power Converter Life Test}

The NASA Glenn Research Center funded a dual phase program to investigate solubility corrosion and to develop coatings that would essentially eliminate the solubility corrosion potential. A complete description of the work performed and the conclusions reached can be found in Dussinger and Lindemuth (1997). The final task of the program was to fabricate a 1/10th segment of the current Stirling Space Power Converter (SSPC), starfish heater head heat pipe, utilizing the coatings and coating processes developed during the program. This heat pipe would then be life tested for up to ten years by Thermacore as Phase 3. Unfortunately, the heat pipe intended for life testing had several weld failures after charging and processing. Because this pipe was no longer available, NASA acquired the original $1 / 10$ th segment heat pipe from Mechanical Technology Incorporated (MTI) and provided it for testing in the Phase 3 effort. The 1/10th segment heat pipe, fabricated by Thermacore for the SSPC project under MTI Subcontract No. 003-05034, was returned to Thermacore for testing on this program.

The starfish heater head heat pipe is doughnut shaped with an inner diameter of 30 centimeters and an outer diameter of 90 centimeters and has a thickness of 10 centimeters. Internal to the doughnut are fifty radial fins with 38 one-millimeter diameter gas passages in each fin. The helium working fluid in the converter flows through the gas passages while the sodium in the heat pipe condenses on the outside of each fin. The inner diameter of the annular heat pipe is attached to the outer diameter of the starfish heater head. The $1 / 10$ th segment is a $36^{\circ}$ slice of the overall heater head and heat pipe. The 38 small diameter helium gas passages are replaced with five larger diameter passages to allow for installation of a gas gap, water cooled, calorimeter to remove and measure the heat flow. Several photographs of the 1/10th segment are shown in figure 1 . The design specifications for this heat pipe are given in table 1.

Figure 2 is a photograph of the $1 / 10$ th segment life test setup. The heat pipe is heated primarily by radiation from twelve silicon carbide heating elements. In order to minimize heat loss, the heating elements are surrounded by a nine-inch thick graded insulation package. The insulation package is formed to fit and support the heat pipe/calorimeter package. The power is controlled with a phase angle power controller in conjunction with a PID temperature controller. The Silicon Carbide heating elements operate in series at a relatively low voltage, approximately 30 volts. A $10 \mathrm{kVA}$ step down transformer is used to reduce the primary 208 to $35 \mathrm{~V}$.

The desired operating temperature is set on the PID temperature controller. The input signal to the temperature controller is the heat pipe vapor space temperature (Type $\mathrm{K}$ thermocouple). The temperature controller sends a control signal to the phase angle power controller to increase or decrease power to maintain the heat pipe at the set point. The temperature controller also has a latching, over temperature alarm feature. In addition, the temperature controller has a second control feature that is being used to energize the hour meter when the temperature is within five degrees of the set point.

Table 1.-Design specifications for $1 / 10$ th segment heat pipe

\begin{tabular}{|l|c|}
\hline \multicolumn{1}{|c|}{ Parameter } & Specification \\
\hline Operating temperature, $\mathrm{K}\left({ }^{\circ} \mathrm{C}\right)$ & $1023 \mathrm{~K}\left(750^{\circ} \mathrm{C}\right)$ \\
\hline Working fluid and fluid charge $(\mathrm{g})$ & 100 high purity sodium \\
\hline Heat transport (throughput) $(\mathrm{W})$ & 4500 \\
\hline Condenser surface heat flux $\left(\mathrm{W} / \mathrm{cm}^{2}\right)$ & 20 \\
\hline Envelope material and fill tube material & In 718 envelope; $316 \mathrm{~L} \mathrm{SS} \mathrm{fill} \mathrm{tube}$ \\
\hline Wick structure material & $316 \mathrm{~L} \mathrm{SS} ;$ two layers 100 mesh screen \\
\hline Arteries & four; $0.318 \mathrm{~cm}(0.125$ inch $)$ inner diameter \\
\hline Artery material & $316 \mathrm{~L} \mathrm{SS} ; 325$ mesh screen \\
\hline
\end{tabular}




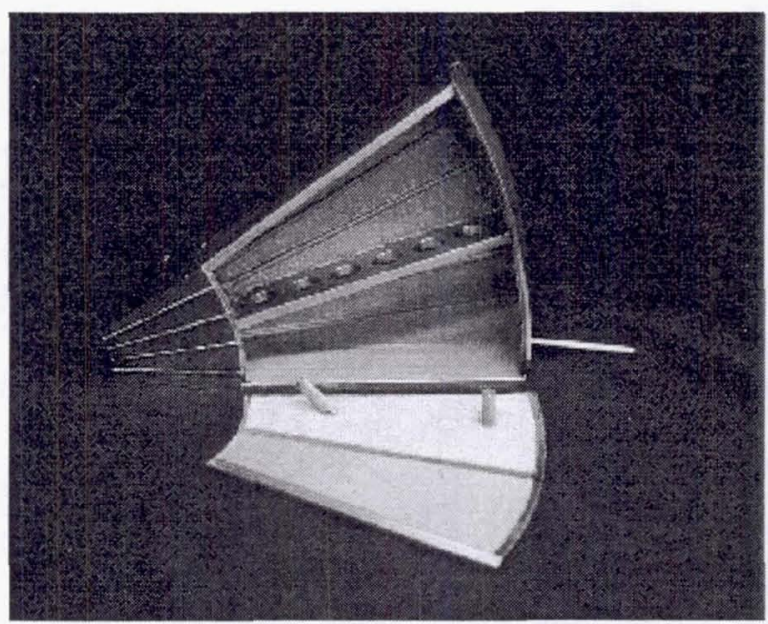

(a) Tenth segment heat pipe with top plate removed to show wick structure

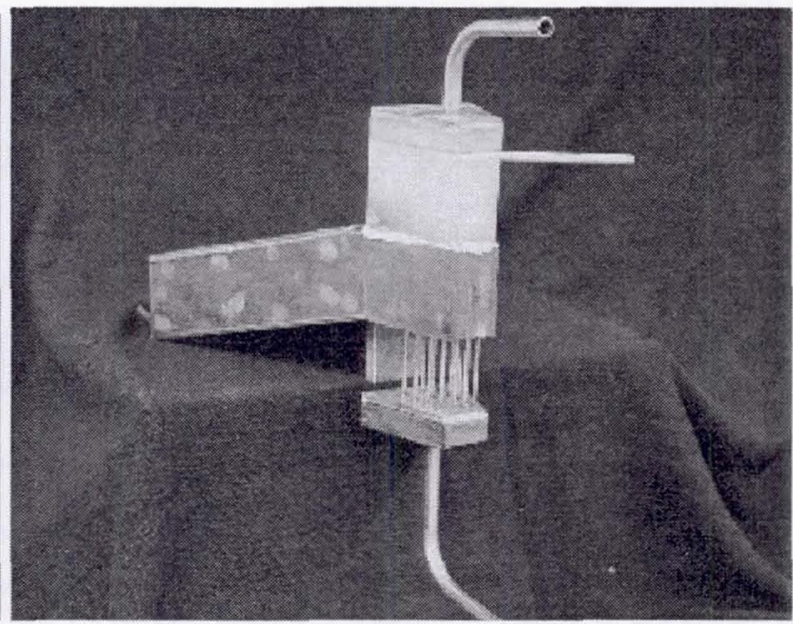

(b) Assembled tenth segment heat pipe with integral calorimeter

Figure 1.- Internal and external views of the tenth segment life test heat pipe.

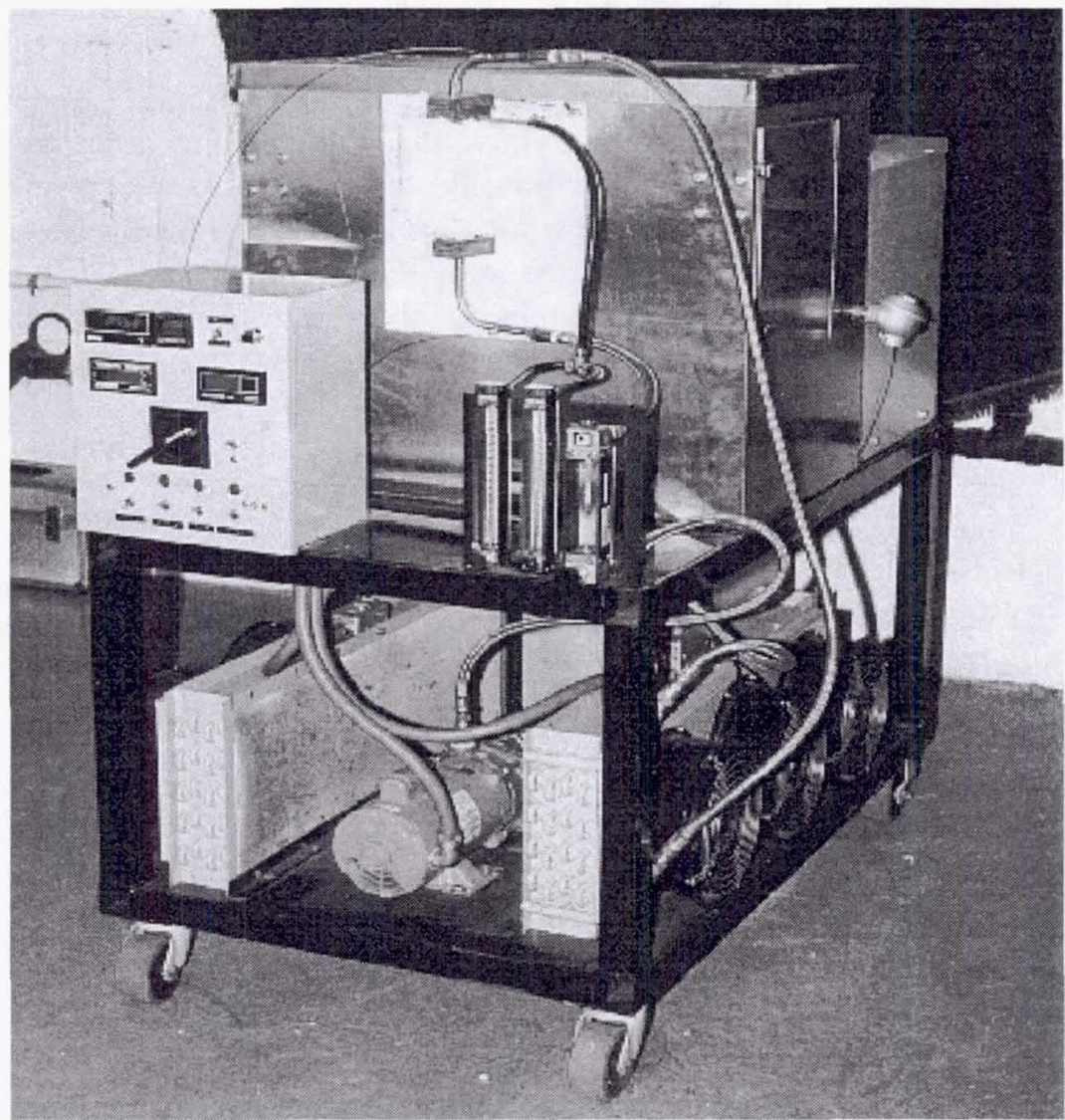

Figure 2.-Completed assembly of the 1/10th segment life test heat pipe. 
The power that the heat pipe transfers is extracted and measured using a gas gap calorimeter. The gas gap calorimeter consists of small diameter water tubes that are inserted into the heater head gas passage holes. The gap between the heater head holes and the water tubes outer diameter is filled with a mixture of helium and nitrogen gas. This arrangement results in the calorimeter water tube, a gas gap, and the heat pipe wall. The sodium vapor generated in the evaporator section of the heat pipe condenses on the Starfish heater head webs releasing its latent heat of vaporization. The thermal energy is transferred through the thickness of the heater head web by conduction. Next, the energy is transferred across the gas-gap by radiation and by conduction through the gas. By controlling the fraction of nitrogen, a low thermal conductivity gas, and the fraction of helium, a high thermal conductivity gas, in the gas gap, the resistance to conduction across the gap can be modulated. The heat is then transferred through the water tube wall by conduction and transferred by convection to the water flowing through the water tubes. The temperature rise of the water flowing through the tubes and the flow rate are used to calculate the heat pipe power throughput. The distilled water coolant is pumped from a tank under the test setup, through a 50 micron filter, and into the calorimeter. The coolant exiting the calorimeter then flows through two liquid-to-air heat exchangers, which are also mounted under the test setup. Heat is ultimately rejected to the room air.

As of September 15,2003, the one-tenth segment life test assembly has logged over 42,700 hours of operation, and a continuation of this life test is planned.

\section{Bench-Top Life Test Heat Pipe}

A bench-top life test heat pipe was fabricated to demonstrate the compatibility and life of a $69 \mathrm{~kW}_{\mathrm{e}}$ $\left(52 \mathrm{~kW}_{\text {th }}\right)$ bench-top test heater for Stirling Engines. For the application, the sodium working fluid evaporates from nickel wick covered tubes, condenses on the heater tubes of the Stirling engine and returns to the evaporator by gravity. Application requirements included a test heater life of 2000 hours and an expected vibration of 0.4 to $0.6 \mathrm{~mm}$ at $60 \mathrm{~Hz}$.

The life test heat pipe was a $4 \mathrm{~kW}_{\mathrm{e}}$ scaled demonstrator for the bench-top heat pipe, pictured in figure 3. Design specifications are given in table 2. The materials of construction are stainless steel heat pipe envelope, sodium working fluid and nickel powder wick structures. In the life test heat pipe, sodium evaporates from nickel powder wick covered tubes, condenses on the wall and end-cap of the heat pipe, and returns to the evaporator by gravity. The heat pipe has a diameter of 3.0 in., a length of $14.0 \mathrm{in}$., and an overall height of $24.0 \mathrm{in}$., including a $10.0 \mathrm{in}$. support stand for the heat pipe. Four $1000 \mathrm{~W}, 240 \mathrm{~V}$ cartridge heaters are used to evaporate the sodium working fluid. The cartridge heaters have a diameter of 0.5 in., a heated length of 6.7 in., and a total length of $12.0 \mathrm{in}$. The heaters were brazed (with Nicrobraze 10) into stainless steel tubes covered with nickel powder wick structures. Four tubes are welded into a stainless steel end-cap which is welded into one end of the main heat pipe tube. The stainless steel fill tube and two thermocouple tubes are welded into the end-cap which is welded into the opposite end of the heat pipe tube. The two thermocouples are used to measure the heat pipe vapor temperature.

Two life test heat pipes were fabricated and processed with sodium. Life test heat pipe no. 2 operated for 200 hours at approximately $650^{\circ} \mathrm{C}$ before failing. A failure analysis showed voids in the braze joint between a cartridge heater and a stainless steel tube. This caused the heater temperature to exceed the melt temperature of the tube and an opening in the melt region of the tube exposed the heat pipe to ambient air, oxidizing the sodium causing the heat pipe to fail. Improved brazing techniques and ultra sonic inspection of the parts prior to assembly will reduce the risk of failure in the future. Life test heat pipe no. 1 operated for 200 hours at approximately $650{ }^{\circ} \mathrm{C}$ before being subjected to $1 \mathrm{~mm}$ peak-to-peak ( $0.5 \mathrm{~mm}$ amplitude) vibration. After the vibration testing was complete, the testing was resumed and life test heat pipe no. 1 has currently operated for over 115,000 hours at approximately $650{ }^{\circ} \mathrm{C}$. The life test is continuing. 


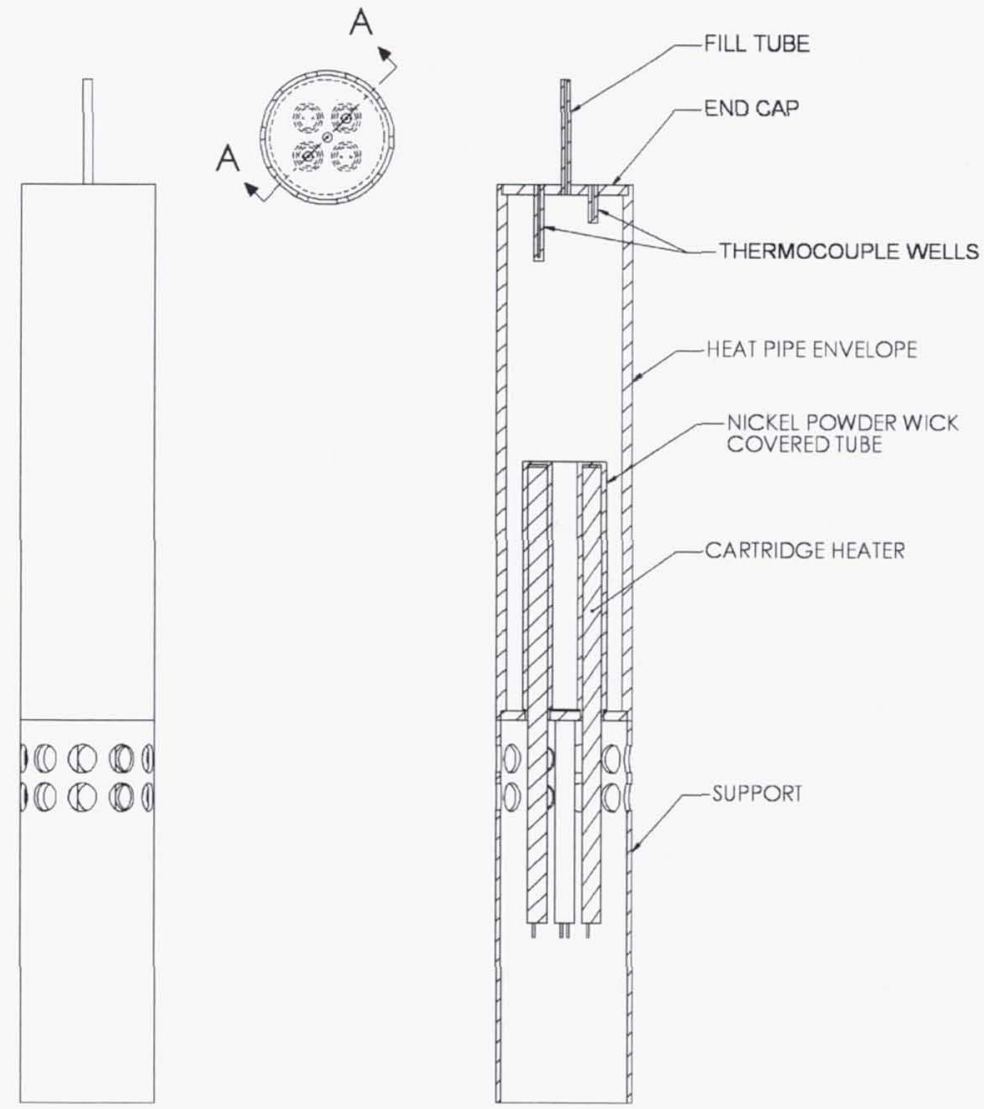

Figure 3.-Bench-top life test heat pipe.

Table 2.-Bench-top life test heat pipe design specifications

\begin{tabular}{|l|c|}
\hline \multicolumn{1}{|c|}{ Parameter } & Specification \\
\hline Heater electrical power (kW) & $4 \mathrm{~kW}$ \\
\hline Working fluid & Sodium (100 grams) \\
\hline Heat pipe envelope material & Stainless steel 316L \\
\hline Wick material & 24.0 \\
\hline Total height (in.) & 14.0 \\
\hline Heat pipe height (in.) & 10.0 \\
\hline Support height (in.) & 3.0 \\
\hline Heat pipe diameter (in.) & 4 \\
\hline Number of heaters & 1000 \\
\hline Heater power (W) & 240 \\
\hline Heater voltage (V) & 12.0 \\
\hline Total length (in.) & 6.7 \\
\hline Heated length (in.) & 0.50 \\
\hline Diameter (in.) & Wall colmonoy nicrobraze 10 \\
\hline Heater-to-tube braze material & welded \\
\hline Heat pipe envelope joints & \\
\hline
\end{tabular}




\section{Sodium Heat Pipe with Pressure Relief Device}

A major concern for a heat pipe heated Solar Dish Stirling System is the rupture of a heater head tube of the Stirling engine. The heater head tubes are inside a hemispherical sodium heat pipe and if the rupture occurred while the heat pipe was in operation, the hemispherical evaporator, solar absorber surface, would invert and cause severe damage to the solar dish and the environment. By installing a Pressure Relief Device (PRD) in the heat pipe, a catastrophic heater head failure at temperature could control the sodium and gas discharge and minimize damage to the system and environment. A $316 \mathrm{~L}$ stainless steel heat pipe with a specially-designed Inconel 601 rupture disk was designed, built, and tested to demonstrate this concept (fig. 4). A low risk, double rupture disc, design was selected for development and test. The Inconel 601 alloy rupture disc is 0.003 in. thick, with score marks leaving the base material as thin as 0.0005 in. thick. One of the design requirements was for the system to operate for 10 years. Therefore, the thin membrane is exposed to atmospheric conditions for 10 years at an operating temperature of $675^{\circ} \mathrm{C}$, and was perceived to have a risk of a vacuum leak failure; the thin membrane has to maintain vacuum integrity. A second PRD was installed to protect the first PRD from corrosion and degradation from the environment. However the two PRDs had to work simultaneously, with one at $675^{\circ} \mathrm{C}$ and the other near ambient temperature. A vacuum was hermetically sealed between the two PRDs. Since there are no data on PRDs at elevated temperature with exposure to sodium vapor, it was decided that a life test would be appropriate. Another concern was some data showing nickel solubility in sodium and sodium vapor impinging on a thin membrane could cause erosion to the surface.

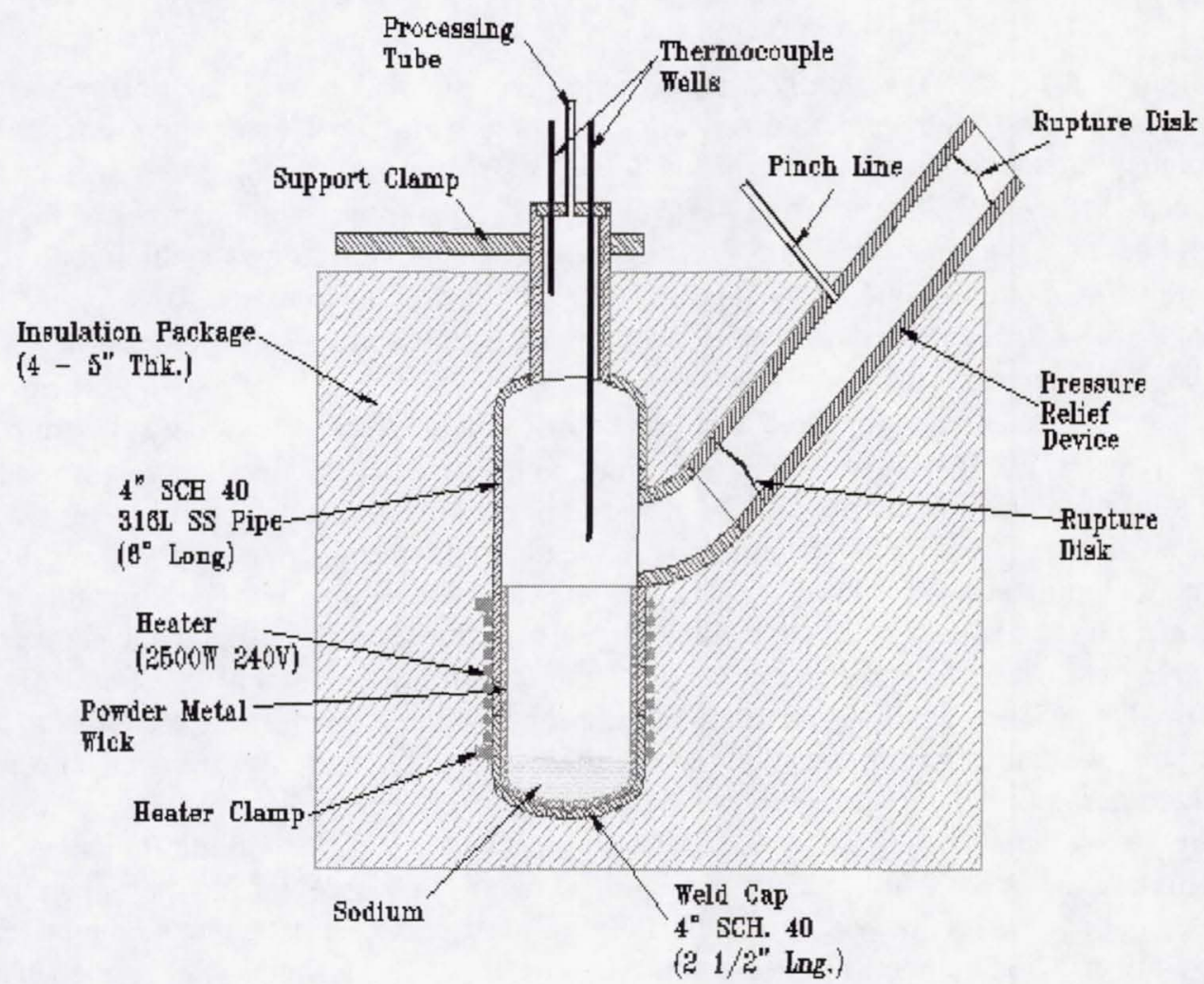

Figure 4.- Pressure relief device life test assembly. 
The pressure relief device life test heat pipe was constructed from $316 \mathrm{~L}$ stainless steel. There was a coarse nickel wick sintered to the base and lower portion of the cylindrical structure to represent a solar receiver. The cal-rod heater was brazed on to the outside diameter of the heat pipe, to assure good thermal contact thus preventing the heater from over-heating and failing. Two thermocouple wells were placed in the vapor space. The heat pipe was evacuated, helium leak detected and charged with 200 grams of sodium. The heat pipe was processed and operated at $675^{\circ} \mathrm{C}$. The heat pipe has undergone several on-off thermal cycles, and has operated for over 83,000 hours as of September 15, 2003. Testing is continuing on this device.

\section{Hybrid Receiver Life Test}

A hybrid application of high temperature heat pipes is for use in Stirling receivers, in which the heat pipe can absorb heat from solar energy and/or a combustion chamber. A hybrid sodium heat pipe receiver with a Haynes 230 envelope and a sintered porous nickel wick structure was designed, built, and tested (Hartenstine and Dussinger, 1994). The full-scale hybrid receiver was tested with a natural gas burner heat source and an array of radiant heaters to simulate solar energy. The design specifications and test plan are presented in the above reference; however, the test results have not been published previously. The heat pipe was operated for nearly 20,000 hours at $700{ }^{\circ} \mathrm{C}$ with no signs of degradation. Life testing was discontinued after this time because of a lack of continuing funding, and the device was dismantled.

\section{Conclusions}

Four sodium heat pipes have recently demonstrated favorable materials compatibility and heat transport characteristics at high temperatures while operating in air over long time periods. A 316L stainless steel heat pipe with a sintered porous nickel wick structure and an integral brazed cartridge heater has successfully operated at 650 to $700{ }^{\circ} \mathrm{C}$ for over 115,000 hours without signs of failure. A $316 \mathrm{~L}$ stainless steel heat pipe with a specially-designed Inconel 601 rupture disk and a sintered nickel powder wick has demonstrated over 83,000 hours at 600 to $650{ }^{\circ} \mathrm{C}$ with similar success. A representative onetenth segment Stirling Space Power Converter heat pipe with an Inconel 718 envelope and a stainless steel screen wick has operated for over 41,000 hours at nearly $700^{\circ} \mathrm{C}$. A hybrid (i.e., gas-fired and solar) heat pipe with a Haynes 230 envelope and a sintered porous nickel wick structure was operated for about 20,000 hours at nearly $700^{\circ} \mathrm{C}$ without signs of degradation. These life tests collectively provide strong evidence for long-term chemical compatibility of sodium heat pipes at high operating temperatures. Accordingly, alkali metal heat pipes will continue to be adopted for an increasing number of important energy conversion applications for the aerospace, military and energy sectors. These include high heat flux, heat pipe cooling of re-entry vehicle leading edges, heat transport from space nuclear reactors to the energy converters and waste heat radiators, fuel cells and gas turbine re-combustors. Some of these technologies will be mission enabling for some of the proposed interplanetary explorations to Jupiter and Venus, where the extreme environments will require thermal management technologies outside of the conventional temperature range.

In addition, work needs to commence in the development of heat pipe working fluids/envelope combinations operating in the "intermediate temperature range" of 450 to $750 \mathrm{~K}$ where there is a dearth of data. While not covered by this paper, it is the authors' personal experience that heat pipes fabricated with sodium-compatible envelopes, but using potassium as the working fluid, will experience the same life times as the sodium heat pipes. In contrast, a heat pipe with lithium working fluid requires the use of a refractory metal envelope. These wall materials include $\mathrm{Nb}-1 \% \mathrm{Zr}, \mathrm{TZM}, \mathrm{T}-111$, vacuum arc-cast tungsten, or other similar alloys which include oxygen getters (Eastman, Ernst, Shaubach, and Toth, 1990). 


\section{References}

Dussinger, P.M., and Lindemuth, J.E., Insoluble Coatings for Stirling Engine Heat Pipe Condenser Surfaces, Final Report NASA CR-202323, NASA Contract No. NAS3-26925, July 1997.

Hartenstine, J.R., and Dussinger, P.M., Development of a Solar and Gas-fired Heat Pipe Receiver for the Cummins Power Generation 7.5 kWe Dish/Stirling System," AIAA Paper No. AIAA-94-3864-CP, 1994.

Rosenfeld, J.H. and Ernst, D.M., "Advances in Refractory Metal Heat Pipe Technology," Heat Pipe Science and Technology: Proc. 11th Int. Heat Pipe Conf., Tokyo, Japan, 1999, pp. 407-413.

Eastman, G.Y., Ernst, D.M., Shaubach, R.M., and Toth, J.E., "Advanced Heat Pipe Technology for Space Heat Transport and Rejection Technologies," Space Power, vol. 9, no. 1, 1990. 
Public reporting burden for this collection of information is estimated to average 1 hour per response, including the time for reviewing instructions, searching existing data sources, gathering and maintaining the data needed, and completing and reviewing the collection of information. Send comments regarding this burden estimate or any other aspect of this collection of information, including suggestions for reducing this burden, to Washington Headquarters Services, Directorate for Information Operations and Reports, 1215 Jefferson Davis Highway, Suite 1204, Arlington, VA 22202-4302, and to the Office of Management and Budget, Paperwork Reduction Project (0704-0188), Washington, DC 20503.

\section{\begin{tabular}{l|l|l|} 
1. AGENCY USE ONLY (Leave blank) & 2. REPORT DATE & 3. REPORT TYPE AND DATES COVERED
\end{tabular}}

\begin{tabular}{r|r|r} 
Technical Memorandum & March 2004
\end{tabular}

4. TITLE AND SUBTITLE 5. FUNDING NUMBERS

An Overview of Long Duration Sodium Heat Pipe Tests

6. AUTHOR(S)

WBS-22-972-20-01

John H. Rosenfeld, Donald M. Ernst, James E. Lindemuth, James L. Sanzi,

Steven M. Geng, and Jon Zuo

7. PERFORMING ORGANIZATION NAME(S) AND ADDRESS(ES)

National Aeronautics and Space Administration

John H. Glenn Research Center at Lewis Field

Cleveland, Ohio 44135-3191

8. PERFORMING ORGANIZATION

REPORT NUMBER

E-14407

9. SPONSORING/MONITORING AGENCY NAME(S) AND ADDRESS(ES)

10. SPONSORING/MONITORING AGENCY REPORT NUMBER

National Aeronautics and Space Administration

Washington, DC 20546-0001

NASA TM-2004-212959

\section{SUPPLEMENTARY NOTES}

Prepared for the Space Technology and Applications International Forum (STAIF-2004) sponsored by the American Institute of Physics, Albuquerque, New Mexico, February 8-12, 2004. John H. Rosenfeld, Donald M. Ernst, James E. Lindemuth, and James L. Sanzi, Thermacore International, Inc., 780 Eden Road, Lancaster, Pennsylvania 17601; Steven M. Geng, NASA Glenn Research Center; and Jon Zuo, Advanced Cooling Technologies, Inc., 1046 New Holland Avenue, Lancaster, Pennsylvania 17601. Responsible person, Steven M. Geng, organization code 5490, 216-433-6145.

12a. DISTRIBUTION/AVAILABILITY STATEMENT 12b. DISTRIBUTION CODE

Unclassified - Unlimited

Subject Category: 34

Distribution: Nonstandard

Available electronically at http://gltrs.grc.nasa.gov

This publication is available from the NASA Center for AeroSpace Information, 301-621-0390.

13. ABSTRACT (Maximum 200 words)

High temperature heat pipes are being evaluated for use in energy conversion applications such as fuel cells, gas turbine re-combustors, and Stirling cycle heat sources; with the resurgence of space nuclear power, additional applications include reactor heat removal elements and radiator elements. Long operating life and reliable performance are critical requirements for these applications. Accordingly long-term materials compatibility is being evaluated through the use of high temperature life test heat pipes. Thermacore International, Inc., has carried out several sodium heat pipe life tests to establish long term operating reliability. Four sodium heat pipes have recently demonstrated favorable materials compatibility and heat transport characteristics at high operating temperatures in air over long time periods. A $316 \mathrm{~L}$ stainless steel heat pipe with a sintered porous nickel wick structure and an integral brazed cartridge heater has successfully operated at 650 to $700{ }^{\circ} \mathrm{C}$ for over 115,000 hours without signs of failure. A second $316 \mathrm{~L}$ stainless steel heat pipe with a specially-designed Inconel 601 rupture disk and a sintered nickel powder wick has demonstrated over 83,000 hours at 600 to $650^{\circ} \mathrm{C}$ with similar success. A representative one-tenth segment Stirling Space Power Converter heat pipe with an Inconel 718 envelope and a stainless steel screen wick has operated for over 41,000 hours at nearly $700{ }^{\circ} \mathrm{C}$. A hybrid (i.e. gas-fired and solar) heat pipe with a Haynes 230 envelope and a sintered porous nickel wick structure was operated for about 20,000 hours at nearly $700{ }^{\circ} \mathrm{C}$ without signs of degradation. These life test results collectively have demonstrated the potential for high temperature heat pipes to serve as reliable energy conversion system components for power applications that require long operating lifetime with high reliability. Detailed design specifications, operating history, and test results are described for each of these sodium heat pipes. Lessons learned and future life test plans are also discussed.

14. SUBJECT TERMS

Heat pipes; Stirling cycle

17. SECURITY CLASSIFICATION OF REPORT

Unclassified

\section{SECURITY CLASSIFICATION OF THIS PAGE}

Unclassified
19

9. SECURITY CLASSIFICATION
OF ABSTRACT
Unclassified

15. NUMBER OF PAGES

15

16. PRICE CODE

20. LIMITATION OF ABSTRACT 